\title{
Wendlandia tinctoria (Roxb.) DC. (Rubiaceae), a key nectar source for butterflies during the summer season in the southern Eastern Ghats, Andhra Pradesh, India
}

\author{
A.J. Solomon Raju ${ }^{1}$, K. Venkata Ramana ${ }^{2} \&$ P. Vara Lakshmi ${ }^{3}$ \\ 1,2,3 Department of Environmental Sciences, Andhra University, Visakhapatnam, Andhra Pradesh 530003, India \\ Email: ${ }^{1}$ ajsraju@yahoo.com (corresponding author), ${ }^{3}$ varalakshmi83@gmail.com
}

\begin{abstract}
Wendlandia tinctoria is a semi-evergreen tree species. It shows massive flowering for about a month during March-April. The floral characteristics such as the white colour of the flower, lack of odour, short-tubed corolla with deep seated nectar having $15-18 \%$ sugar concentration are well tailored for visitation by butterflies. The nectar is hexose-rich and contains the essential amino acids such as arginine and histidine and the nonessential amino acids such as alanine, aspartic acid, cysteine, glysine, hydroxyproline, tyrosine, glutamic acid and serine. The inflorescences with clusters of flowers provide an excellent platform for foraging by butterflies. The flowers are long-lived and attractive to butterflies. A variety of butterflies visit the flowers for nectar and in doing so, they pollinate them. Nymphalids are very diverse and utilize the flowers until exhausted. The flowers being small in size with a small amount of nectar compel the butterflies to do a more laborious search for nectar from a greater number of flowers. But, the clustered state of the flowers is energetically profitable for butterflies to reduce search time and also flight time to collect a good amount of nectar; such a probing behaviour is advantageous for the plant to achieve self- and cross-pollination. Therefore, the study shows that the association between $W$. tinctoria and butterflies is mutual and such an association is referred to as psychophilous. This plant serves as a key nectar source for butterflies at the study site where floral nectar sources are scarce during the summer season.
\end{abstract}

Keywords: Butterflies, nectar source, psychophily, Wendlandia tinctoria.

Date of publication (online): 26 March 2011

Date of publication (print): 26 March 2011

ISSN $0974-7907$ (online) | 0974-7893 (print)

Editor: K.R. Sasidharan

Manuscript details:

Ms \# 02503

Received 06 July 2010

Final received 26 October 2010

Finally accepted 15 February 2011

Citation: Raju, A.J.S., K.V. Ramana \& P.V. Lakshmi (2011). Wendlandia tinctoria (Roxb.) DC. (Rubiaceae), a key nectar source for butterflies during the summer season in the southern Eastern Ghats, Andhra Pradesh, India. Journal of Threatened Taxa 3(3): 1594-1600.

Copyright: ( ) A.J. Solomon Raju, K. Venkata Ramana \& P. Vara Lakshm 2011. Creative Commons Attribution 3.0 Unported License. JoTT allows unrestricted use of this article in any medium for non-profit purposes, reproduction and distribution by providing adequate credit to the authors and the source of publication.

OPEN ACGESS | FREE DOWNLOAD
Adult butterflies that visit a wide variety of available flowers are considered to be opportunistic foragers (Courtney 1986). However, studies conducted to date, indicate that butterfly species show distinct flower preferences (Erhardt \& Thomas 1991). Later, Kunte (2000) also stated that butterflies do not feed indiscriminately from any flower that they might find. They prefer certain floral nectars with specific chemical composition. Their visits to different flowers also depend on other factors like floral colour, shape, size, position and arrangement in the inflorescence. For a butterfly, a flower must offer a reasonable reward, yet may physically restrict access to the reward. Access may be limited by a complex flower structure demanding particular foraging skills. Faegri \& van der Pijl (1979) stated that the floral features such as large, red or blue, narrow, tubular flowers with deep nectaries and often yellow rings or other markings on the petals which function as nectar guides are important for butterfly visitation. Gunathilagaraj et al. (1998) reported that butterfly flowers are often regular, tubular and sweet-smelling. Butterfly flower is typified by red, yellow or blue upright flowers that have diurnal anthesis. Opler (1983) suggested that corolla colour and shape, positioning of sexual parts, position on plant, presence of nectar guides, fragrance, and time of anthesis play important roles in the selection of flower foragers. Baker \& Baker $(1982,1983)$ described

This article is part of the peer-reviewed Proceedings of the $3^{\text {rd }}$ Asian Lepidoptera Conservation Symposium (3ALCS-2010) jointly organized by the IUCN SSC South Asian Invertebrate Specialist Group (SAsISG); Department of Zoology, Bharathiar University; Zoo Outreach Organisation and Wildlife Information Liaison Development, held from 25 to 29 October 2010 at Coimbatore, Tamil Nadu, India http://www.zooreach.org/3alcs2010.html 
two categories of flowers with reference to flowerbutterfly relationships. The first category is "true butterfly flowers" which are characterized by deep, narrow corolla tubes with relatively copious sucroserich nectar. The second category is "bee and butterfly flowers" which are characterized by short-tubed corolla with hexose-rich nectar for which Asteraceae members have been shown to be excellent examples. The findings of the present study on the floral biology of Wenlandia tinctoria and its mutual association with butterflies have been examined in the light of these generalizations in order to adjudicate $W$. tinctoria as a key nectar resource for butterflies during the summer season at the study site.

\section{Materials and Methods}

Wendlandia tinctoria trees occurring at the Seshachalam Hills of the southern Eastern Ghats
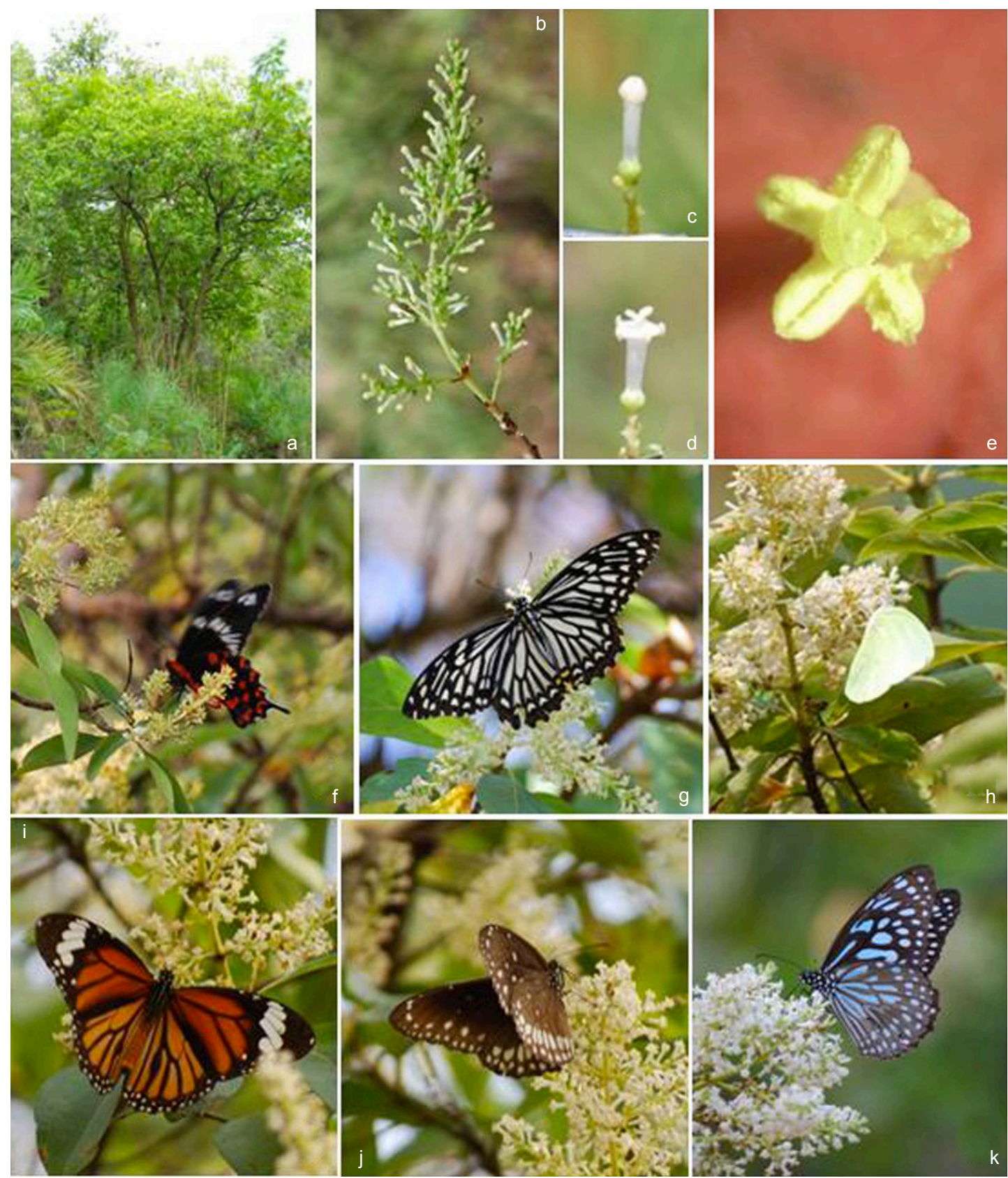

Image 1. Wendlandia tinctoria

a - habit; b - inflorescence; c - bud; d \& e - flower; f - Pachilopta hector; g - Papilio clytia; h - Catopsilia pyranthe; i - Danaus genutia; j - Euploea core; $\mathbf{k}$ - Tirumala septentrionis 
of Andhra Pradesh were used for the study during the summer season of 2009. The details of flower morphology such as flower sex, shape, size, colour, odour, sepals, petals, stamens and ovary were described. Ten fresh flowers were used to measure the total volume of nectar/flower. The nectar sugar concentration was measured by using a Hand Sugar Refractometer (Erma, Japan) as per Dafni et al. (2005). Nectar analysis for sugar types was done as per the Paper Chromatography method of Harborne (1973). Nectar analysis for amino acid types was done as per the Paper Chromatography method of Baker and Baker (1973). Regular observations were made on butterflies visiting the flowers for nectar to record the number of foraging visits species-wise and then family-wise in order to assess the importance of $W$. tinctoria as a key nectar source during the summer season.

\section{Results}

Plant phenology and Floral biology: Wendlandia tinctoria is a semi-evergreen tree species with scattered distribution in the forest (Image 1a). The field surveys in the entire forest area covering an extent of $50 \mathrm{~km}^{2}$ showed that the population of this species is limited to about 25 trees only. The leaves are glabrous and elliptic-lanceolate borne opposite each other. New leaf flushing occurs during the rainy season adding a bright green look to the foliage. The flowering occurs from the third week of March to the third week of April. The flowering is almost synchronous in all individuals. The flowers are borne in clusters of terminal paniculate inflorescences (Image 1b). The flowers open at 0600 $\mathrm{hr}$ (Image 1c-e). The petals unfold exposing the stigma and stamens beyond the length of the corolla tube. The flowers are small, 6-7 mm long, tubular, white with a yellow tinge, odourless, regular and bisexual. The calyx is very small with five light green fused sepals. The corolla is tubate tipped with five lobes, $5 \mathrm{~mm}$ long, white and conceals nectar. The stamens are five each with dithecous anthers having versatile fixation, very small and situated below the stigma; the anthers appear star-like at the mature bud stage but take different postures after anthesis. The style is erect and terminated with spathulate bifid stigma. Nectar is produced in minute amounts which stands at $0.6 \pm$ $0.12 \mu \mathrm{l}$ per flower and is collected at the base of corolla tube. The nectar sugar concentration ranged from $15 \%$ to $18 \%$; the sugar types include sucrose, fructose

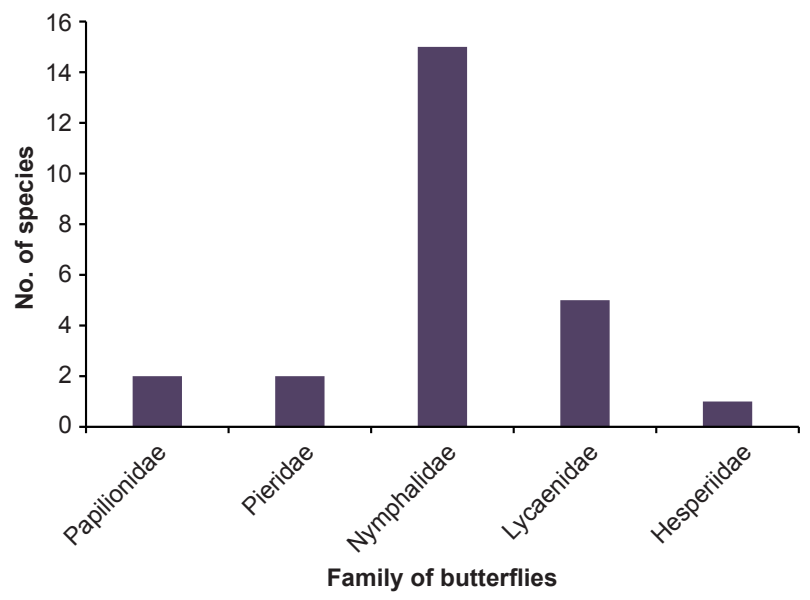

Figure 1. Family-wise number of butterfly species foraging for nectar on Wendlandia tinctoria

and glucose but the last is more dominant. The nectar contains both essential and non-essential amino acids. The essential amino acids are arginine and histidine while non-essential amino acids are alanine, aspartic acid, cysteine, glysine, hydroxyproline, tyrosine, glutamic acid and serine. The flowers remain in place for four days and fall off subsequently.

Foraging activity of butterflies: The butterflies foraging for nectar included 25 species representing Papilionidae, Pieridae, Nymphalidae, Lycaenidae and Hesperiidae (Fig. 1, Table 1). The Papilionidae and Pieridae each was represented by two species, Lycaenidae by five species, Nymphalidae by 15 species, and Hesperiidae by a single species. The papilionids were Pachliopta hector (Image 1f) and Papilio clytia (Image 1g). The pierids were Catopsilia pyranthe (Image $1 \mathrm{~h}$ ) and $C$. pomona. The nymphalids were Danaus genutia (Image 1i), D. chrysippus, Euploea core (Image 1j), Tirumala septentrionis (Image 1k), T. limniace (Image 2a), Hypolimnas bolina (Image 2b), H. misippus (Image 2c), Precis iphita (Image 2d), Phalanta phalantha (Image 2e), Neptis hylas (Image 1f), Junonia lemonias (Image 2g), J. hierta, Ariadne merione, Acraea violae and Parantica aglea (Image 2h). The lycaenids were Jamides celeno (Image 2i), Arhopala amantes (Image 2j), Lampides boeticus (Image 2k), Spindasis vulcanus (Image 2l) and Everes lacturnus. The hesperiid was Borbo cinnara (Image $2 \mathrm{~m}$ ). Of these, the individuals of nymphalid butterflies were more than those of other families at the flowers throughout the flowering season. The data collected on the foraging visits of butterflies of each 
Table 1. List of nectar feeding butterflies on Wendlandia tinctoria

\begin{tabular}{|c|c|}
\hline Scientific Name & Common Name \\
\hline \multicolumn{2}{|l|}{ Papilionidae } \\
\hline Pachliopta hector & Crimson Rose \\
\hline Papilio aglea & Common Mime \\
\hline \multicolumn{2}{|l|}{ Pieridae } \\
\hline Catopsilia pyranthe & Mottled Emigrant \\
\hline C. pomona & Common Emigrant \\
\hline \multicolumn{2}{|l|}{ Nymphalidae } \\
\hline Danaus genutia & Striped Tiger \\
\hline D. chrysippus & Plain Tiger \\
\hline Junonia lemonias & Lemon Pansy \\
\hline Junonia hierta & Yellow Pansy \\
\hline Precis iphita & Chocolate Pansy \\
\hline Euploea core & Common Indian Crow \\
\hline Ariadne merione & Common Castor \\
\hline Acraea violae & Tawny Coster \\
\hline Tirumala septentrionis & Dark Blue Tiger \\
\hline T. limniace & Blue Tiger \\
\hline Hypolimnas bolina & Great Eggfly \\
\hline H. misippus & Danaid Eggfly \\
\hline Phalanta phalantha & Common Leopard \\
\hline Neptis hylas & Common Sailer \\
\hline Parantica aglea & Glassy Tiger \\
\hline \multicolumn{2}{|l|}{ Lycaenidae } \\
\hline Jamides celeno & Common Cerulean \\
\hline Arhopala amantes & Large Oak Blue \\
\hline Lampides boeticus & Pea Blue \\
\hline Spindasis vulcanus & Common Silver Line \\
\hline Everes lacturnus & Indian Cupid \\
\hline \multicolumn{2}{|l|}{ Hesperiidae } \\
\hline Borbo cinnara & Rice Swift \\
\hline \multicolumn{2}{|l|}{ Sphingidae } \\
\hline Cephonodes hylas & Coffee Hawk Moth \\
\hline
\end{tabular}

family showed that nymphalids made $63 \%$, lycaenids $18 \%$, papilionids $9 \%$, pierids $7 \%$, and hesperiids $3 \%$ of total visits (Fig. 2). The aggregated arrangement of flowers provides a comfortable landing place for butterflies and this arrangement also enables them to probe several flowers in each visit in succession for nectar before their departure. The clusters of paniculate inflorescences borne terminally stand out prominently and the butterflies were found to be attracted to them even from a long distance. All

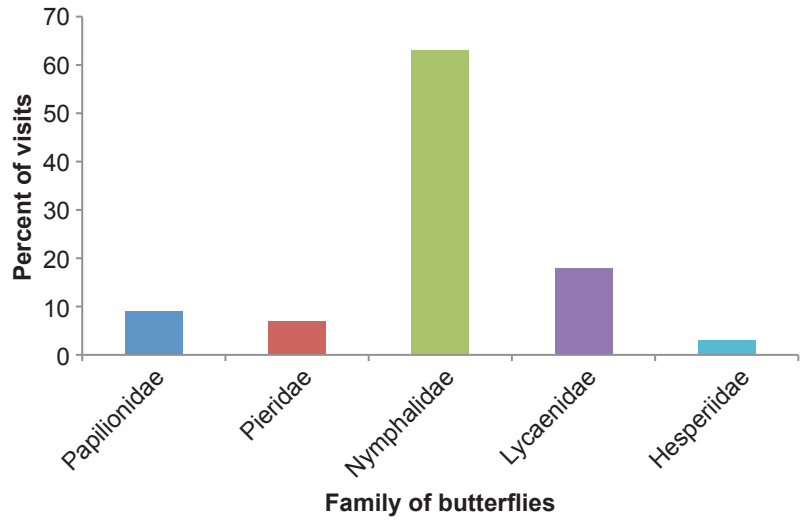

Figure 2. Family-wise percentage of foraging visits of butterflies on Wendlandia tinctoria

these butterflies stretched out their proboscis to reach the floral base to access nectar; while doing so the proboscis invariably contacts the stigmatic lobes and hence effects pollination. The butterflies frequently moved between individual plants of $W$. tinctoria which occur scattered in the forest; this inter-plant foraging activity was considered to be important in promoting cross-pollination. Further, the diurnal hawkmoth, Cephonodes hylas (Image 2n) also foraged for nectar during dawn hours.

\section{Discussion}

Burkhardt (1964) and Faegri \& van der Pijl (1979) characterized butterfly-flowers as mentioned in the introduction section. Baker \& Baker (1983) reported that the short-tubed flowers tend to be hexose-rich and if grouped in conspicuous inflorescences provide an excellent standing platform for foragers, and attract, both butterflies and short-tongued bees. Cruden et al. (1983) also stated that hexose-richness appears to prevail in the nectar of short-tubed flowers. These authors also documented that the nectars of most butterfly-pollinated flowers fall within the range of 15 to $25 \%$ sugar concentration. Kingsolver \& Daniel (1979) suggested that the nectar sugar concentrations of $20-25 \%$ optimize the net energy gain by the butterflies. In $W$. tinctoria, the floral characteristics such as the white colour of the flower, lack of odour, short-tubed corolla with deep seated hexose-rich nectar accounting for 21-26\% sugar concentration characterize psychophily.

Nectar is a potential source of amino acids for the nutrition of butterflies. Naturally, butterfly nectars are 

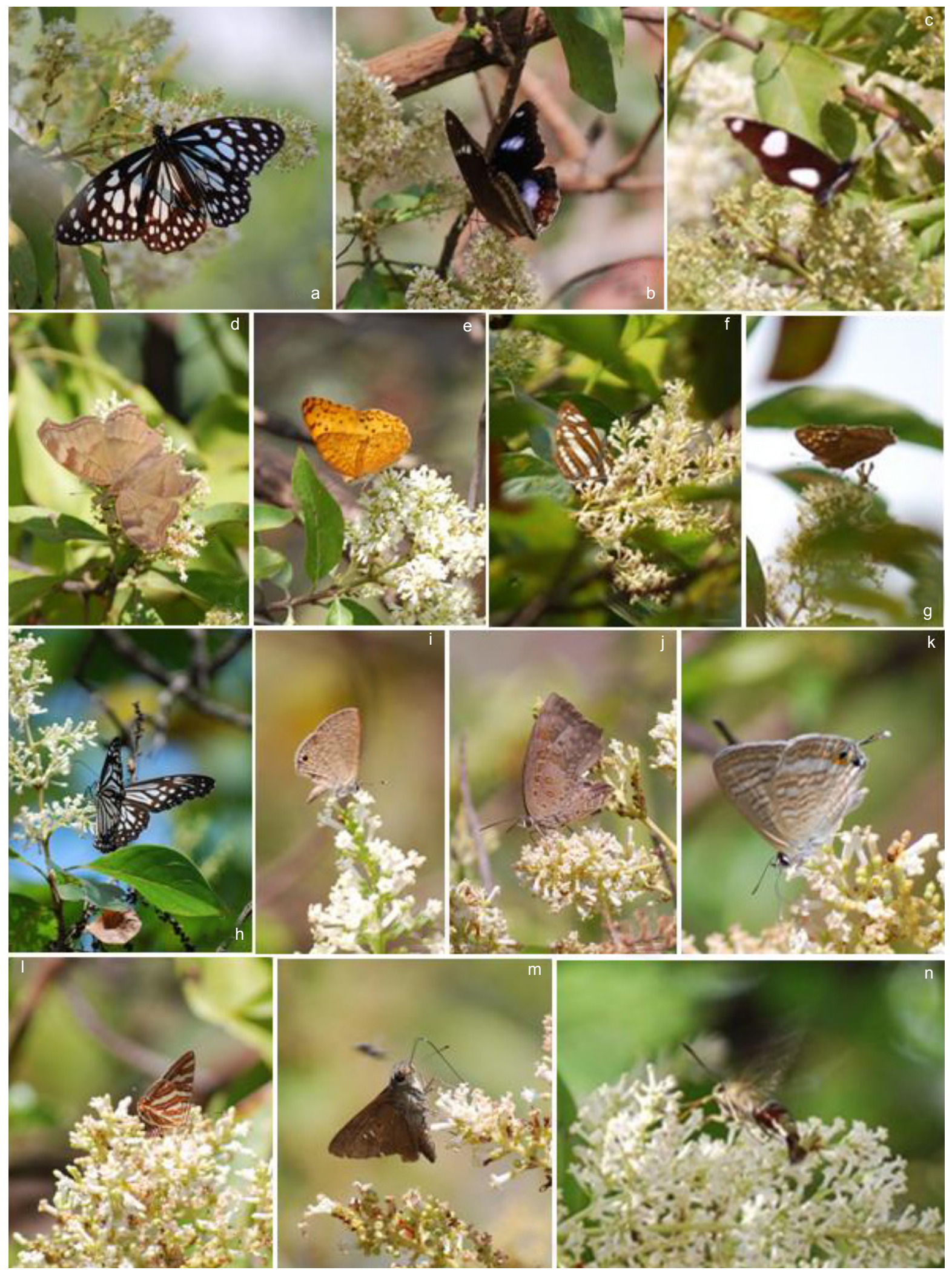

Image 2. Butterflies observed on Wendlandia tinctoria

a - Tirumala limniace; b - Hypolimnas bolina; c - Hypolimnas misippus; d - Precis iphita; e - Phalanta phalantha; f - Neptis hylas; $\mathrm{g}$ - Junonia lemonias; $\mathrm{h}$ - Parantica aglea; $\mathrm{i}$ - Jamides celeno; j - Arhopala amantes; $\mathrm{k}$ - Lampides boeticus; I - Spindasis vulcanus; $\mathrm{m}$ - Borbo cinnara; $\mathrm{n}$ - Cephonodes hylas 
rich in amino acids (Baker \& Baker 1983). Butterflies require ten essential amino acids but all of them are not normally found in all nectars. Usually, three to four essential amino acids and several non-essential amino acids are found in floral nectars (Baker \& Baker 1982; 1983). Baker \& Baker (1986) reported that the amino acids add taste to the floral nectar and it depends on their concentration. Their presence serves as an important cue for butterflies to make flower visits and in the process effect pollination. In W. tinctoria, the nectar contains two essential (arginine and histidine) and eight non-essential amino acids. Its nectar is an important source for two of the ten essential amino acids required by butterflies during adult life for their growth and development (DeGroot 1953). Nonessential amino acids are metabolized by butterflies from the food they take; however, floral nectar provides some of these amino acids instantaneously. The nectar of $W$. tinctoria provides alanine, aspartic acid, cysteine, glysine, hydroxyproline, tyrosine, glutamic acid and serine. Gardener \& Gillman (2002) mentioned that if local soil conditions favour higher amino acids in the nectar then local populations of butterflies may derive certain benefits. Adult feeding on amino acid rich food has been shown to increase longevity and reproductive ability in certain heliconine butterflies (Gilbert 1972; Dunlap-Pianka et al. 1977). A later study on a temperate species Euphydryas editha showed that amino acids in the adult diet led to heavier eggs (Murphy et al. 1983). Jervis \& Boggs (2005) reported that the butterflies are agents of selection for higher nectar amino acid production. The requirement of amino acids during adult stage of the butterfly is related to the larval nutritional condition. The larval food plant has a key role in the evolution of the flower-butterfly mutualism, and demonstrates that the importance to butterfly reproduction, and of different nutrient source varies with butterfly nutritional state. Gardener \& Gillman (2001) reported that soil conditions can affect the amino acid complement of nectar. This may have implications for plant-butterfly interactions, as local populations of butterflies may benefit from the increased amino acid content of the nectar and preferentially visit plants growing in high nutrient conditions. The fidelity of butterflies to $W$. tinctoria during the flowering phase attests the fact that butterflies are in need of amino acids present in this nectar and in the process of acquiring the amino acids, it is contributing to pollination.

In $W$. tinctoria, the inflorescences with clusters of flowers provides an excellent platform for foraging by butterflies. The retention of flowers for four days appears to be an adaptive trait for the plant to enhance its attractiveness to butterflies. With these floral, structural and functional characteristics, W. tinctoria has been found to be foraged by butterflies of all five families of Lepidoptera. The short-tubed flowers facilitate butterflies with any length of proboscis to collect nectar easily. The flowers being small in size with minute amounts of nectar compel the butterflies to do a more laborious search for nectar from a greater number of flowers. But, the clustered state of the flowers is energetically profitable for butterflies to reduce search time and also flight time to collect a good amount of nectar. Overall, the search for nectar by butterflies due to the production of minute amounts of nectar at flower level contributes to both self- and cross-pollination. W. tinctoria attracts more number of individuals and species of nymphalid butterflies when compared to those of other families of butterflies suggesting that nymphalid butterflies use this plant as an important nectar source. The psychophily is advantageous for the plant because butterflies do not collect pollen for themselves but only carry pollen on their proboscis and effect pollination while collecting nectar. Therefore, the study shows that $W$. tinctoria with massive flowering is quite attractive to butterflies and it is a keystone tree species for them since it provides them with nectar for a period of about one month during summer season in the dry deciduous forest ecosystem of Seshachalam Hills. There are no other plant species in flowering which attract a diversity of butterflies to this extent during the flowering period of W. tinctoria and hence this tree species plays a crucial role for the local butterflies for their nutrition for one month during summer season.

\section{REFERENCES}

Baker, H.G. \& I. Baker (1982). Chemical constituents of nectar in relation to pollination mechanisms and phylogeny. pp. 131-171. In: Nitecki, M.H. (ed.). Biochemical Aspects of Evolutionary Biology. The University of Chicago Press, Chicago.

Baker, H.G. \& I. Baker (1973). Some anthecological aspects of the evolution of nectar producing flowers, particularly 
amino acid production in nectar. pp. 243-264, In: Heywood V.H. (ed.). Taxonomy and Ecology. Academic Press, New York.

Baker, H.G. \& I. Baker (1983). Floral nectar sugar constituents in relation to pollinator type. pp. 117-141. In: Jones, C.E. \& R.J. Little (eds.). Handbook of Experimental Pollination Biology. Scientific and Academic Editions, New York.

Baker, H.G. \& I. Baker (1986). The occurrence and significance of amino acids in floral nectar. Plant Systematics \& Evolution 151: 171-186.

Burkhardt, D. (1964). Colour discrimination in insects. Advances in Insect Physiology 3: 131-173.

Courtney, S.P. (1986). The ecology of pierid butterflies: Dynamics and interactions. Advances in Ecological Research 15: 15-31.

Cruden, R.W., S.M. Hermann \& S. Peterson (1983). Plantpollinator coevolution, pp. 80-125, In: Bentley, B. \& T. Elias (eds.). The Biology of Nectaries. Columbia University Press, New York.

Dafni, A., P.G. Kevan \& B.C. Husband (2005). Practical Pollination Biology. Enviroquest Ltd., Cambridge, 590pp.

DeGroot, A.P. (1953). Protein and amino acid requirements of the honey bee (Apis mellifera L.). Physiologia Comparata et Oecologia 3: 197-285.

Dunlap-Pianka, H., C.L. Boggs \& L.E. Gilbert (1977). Ovarian dynamics in heliconiine butterflies: programmed senescence versus eternal youth. Science 197: 487-490.

Erhardt, A. \& J.A. Thomas (1991). Lepidoptera as indicators of change in the semi-natural grasslands of lowland and upland Europe, pp. 213-226: In: Collins, M. \& J.A. Thomas (eds.). The Conservation of Insects and their Habitats. Academic Press, London.
Faegri, K. \& L. van der Pijl (1979). The Principles of Pollination Ecology. Pergamon Press, Oxford, 244pp.

Gardener, M.C. \& M.P. Gillman (2001). The effects of soil fertilizer on amino acids in the floral nectar of corncockle, Agrostemma githago L. (Caryophyllaceae). Oikos 92: 101106.

Gardener, M.C. \& M.P. Gillman (2002). The taste of nectar: a neglected area of pollination ecology. Oikos 98: 552-557.

Gilbert, L.E. (1972). Pollen feeding and reproductive biology of Heliconius butterflies. Proceedings of National Academy of Sciences (USA) 69: 1403-1407.

Gunathilagaraj, K., T.N.A. Perumal, K. Jayaram \& M.G. Kumar (1998). Field Guide: Some South Indian Butterflies. Niligiri Wildlife and Environmental Association, Niligiris, $274 \mathrm{pp}$.

Harborne, J.B. (1973). Phytochemical Methods. Chapman and Hall, London.

Jervis, M.A. \& C.L. Boggs (2005). Linking nectar amino acids to fitness in female butterflies. Trends in Ecology \& Evolution 20: 585-587.

Kingsolver, J.G. \& T.L. Daniel (1979). On the mechanics and energetics of nectar feeding in butterflies. Journal of Theoretical Biology 76: 167-179.

Kunte, K. (2000). India - A Lifescape: Butterflies of Peninsular India. Universities Press, Hyderabad, 254pp.

Murphy, D.D., A. E. Launer \& P.R. Ehrlich (1983). The role of adult feeding in egg production and population dynamics of the checker spot butterfly Euphydryas editha. Oecologia 56: 257-263.

Opler, P.A. (1983). Nectar production in a tropical ecosystem, pp. 30-79. In: Bentley, B. \& T. Elias (eds.). The Biology of Nectaries. Columbia University Press, New York. 